Document downloaded from:

http://hdl.handle.net/10251/67737

This paper must be cited as:

Peris, B.; Navarro-Esbri, J.; Moles, F.; Mota Babiloni, A. (2015). Experimental study of an ORC (organic Rankine cycle) for low grade waste heat recovery in a ceramic industry. Energy. 85:534-542. doi:10.1016/j.energy.2015.03.065.

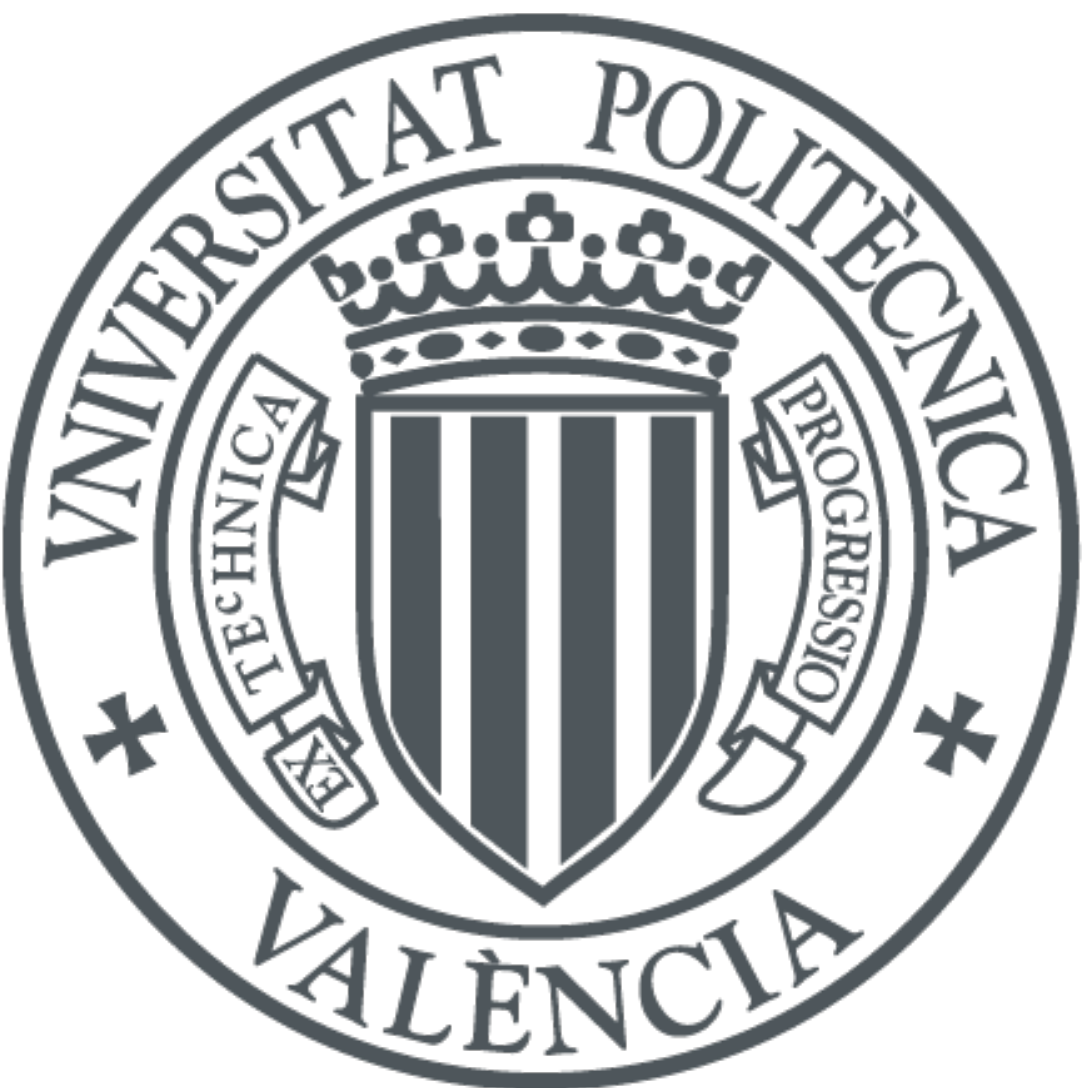

The final publication is available at

http://dx.doi.org/10.1016/j.energy.2015.03.065

Copyright Elsevier

Additional Information 


\title{
Experimental study of an ORC (organic Rankine cycle) for low grade waste heat recovery in a ceramic industry
}

\author{
Bernardo Peris", a , Joaquín Navarro-Esbria, b ${ }^{\text {, Francisco Molés }}{ }^{\text {, }}$, Adrián Mota-Babilonia, c \\ ${ }^{a}$ ISTENER Research Group. Department of Mechanical Engineering and Construction, Campus de Riu Sec s/n, \\ University Jaume I, E12071, Castellón, Spain. \\ ${ }^{\mathrm{b}}$ Expander-Tech, Campus de Riu Sec s/n, University Jaume I, E12071, Castellón, Spain. \\ ${ }^{\mathrm{c}}$ Institute for Industrial, Radiophysical and Environmental Safety, Camino de Vera s/n, Polytechnic University of \\ Valencia, E-46022 Valencia, Spain.
}

\begin{abstract}
This paper deals about an experimental application of an ORC (organic Rankine cycle) in a ceramic industry for low grade waste heat recovery. The ORC module used in this application was initially designed and constructed to satisfy the main specifications for an efficient power system, highlighting a volumetric expander with large built-in volume ratio. Furthermore, the performance of the ORC was experimentally characterized in a test bench in a previous work, achieving a maximum gross electrical efficiency of $12.32 \%$.

Taking this as a starting point, the aim of this work is to verify the performance of this ORC operating in actual industrial conditions, besides to profiting the information extracted from the application to assess its profitability. For this, the system performance is experimentally characterized in the industry, discussing and comparing the results obtained to laboratory data. From these experimental results a model of the system is developed, which allows predicting the net electrical production of the system along a typical year of operation and quantifying the energy and environmental benefits of the project. Moreover, from the electrical generation, investment costs required and industrial electricity price, a feasibility study is conducted to address the profitability of the application.
\end{abstract}

Keywords: ORC (organic Rankine cycle); waste heat recovery; power applications; ceramic industry; energy efficiency.

\footnotetext{
${ }^{*}$ Corresponding Author:

Tel: +34 964728137; fax: +34 964728106.

E-mail address: bperis@uji.es
} 


\begin{tabular}{|ll|}
\hline Nomenclature & specific heat capacity $\left(\mathrm{kJ} \cdot \mathrm{kg}^{-1} \cdot \mathrm{K}^{-1}\right)$ \\
$\mathrm{c}_{\mathrm{p}}$ & enthalpy $\left(\mathrm{kJ} \cdot \mathrm{kg}^{-1}\right)$ \\
$\mathrm{h}$ & mass flow rate $\left(\mathrm{kg} \cdot \mathrm{s}^{-1}\right)$ \\
$\dot{\mathrm{m}}$ & pressure $(\mathrm{bar})$ \\
$\mathrm{P}$ & thermal power $(\mathrm{kW})$ \\
$\mathrm{Q}$ & pressure ratio \\
$\mathrm{r}_{\mathrm{p}}$ & temperature $\left({ }^{\circ} \mathrm{C}\right)$ \\
$\mathrm{T}$ & uncertainty \\
$\mathrm{U}$ & volumetric flow rate $\left(\mathrm{m}^{3} \cdot \mathrm{s}^{-1}\right)$ \\
$\dot{\mathrm{V}}$ & electrical power $(\mathrm{kW})$ \\
$\mathrm{W}$ & \\
Greek symbols & effectiveness $(\%)$ \\
$\varepsilon$ & efficiency $(\%)$ \\
$\eta$ & error bandwidth \\
$\lambda$ & density $\left(\mathrm{kg} \cdot \mathrm{m}^{-3}\right)$ \\
$\rho$ & standard deviation \\
$\sigma$ & error \\
$\chi$ & \\
Subscripts & expander \\
$\mathrm{e}$ & electrical \\
$\mathrm{el}$ & gross \\
$\mathrm{g}$ & heat recovery vapor generator \\
$\mathrm{HRVG}$ & isentropic \\
ise & net \\
$\mathrm{n}$ & thermal oil \\
oil & pump \\
$\mathrm{p}$ & working fluid \\
wf &
\end{tabular}

\section{Introduction}

The ORC (organic Rankine cycle) has been proven as an efficient way for power generation from low grade heat sources [1]. It is a similar power cycle to the steam Rankine cycle, but uses more volatile fluids instead of water to improve the efficiency in low temperature applications [2]. Its operating principle consists of capturing the thermal energy from the heat source through the evaporation of the working fluid and reducing the enthalpy in an expander to produce mechanical work, which is turned into electricity by an electric generator. This is a closed system, which condenses the vapor from the expander outlet and pressurizes the liquid to restart the cycle again. So, it is considered a simple cycle that requires little maintenance, compared to other power cycles like Kalina [3], Goswami, transcritical cycle or trilateral-flash cycle [4]; in addition to its mature and proven technology against direct conversion techniques (thermoelectric, thermionic or piezoelectric) [5].

There are several heat sources and applications in which the ORC can be used, like: solar thermal [6], geothermal [7], oceanic [5], biomass [8], combined heat and power [9], waste heat 
from power plants [10], waste heat from industrial processes [11] or others [12]. Among them, this paper focuses on power generation from industrial waste heat recovery, whose achievable benefits make it an application with great energy, environmental and economic interest. For instance, in Europe it was estimated that the gross electrical power could reach $2.7 \mathrm{GW}$, being able to produce up to 21.6 TWh annually, saving 1,957 million euro per year and reducing 8.1 million tons of greenhouse gas emissions to the atmosphere [13].

Within waste heat from industrial gases there is a wide range of heat source temperatures, with some examples summarized in Table 1. Among them, over $50 \%$ corresponds to low grade waste heat, whose temperatures are generally below 300-350 ${ }^{\circ} \mathrm{C}$ [14]. Therefore, the high availability of industrial low grade waste heat becomes an opportunity for the use of a recovery system based on ORC.

Table 1. Temperatures of industrial gases.

These and other ORC opportunities have motivated researchers' efforts in order to provide suitable solutions. Thus, various experimental studies can be found in the literature, as the work of Zhou et al. [16] that tested an ORC for waste heat recovery from flue gases. The authors used a liquefied petroleum gas stove to simulate the heat source and to control the temperature in the range of 90 to $220^{\circ} \mathrm{C}$. The working fluid selected was R123 and a scroll expander, obtaining a maximum power output of $0.645 \mathrm{~kW}$ and a cycle efficiency of $8.5 \%$. The same working fluid and expander type were used by Lemort et al. [20] and Quoilin et al. [21] in their researches, pointing a maximum cycle efficiency of $7.4 \%$. Pei et al. [22] experimented with a small scale ORC, also using the working fluid R123 and a special design turbine. Their results showed an ORC efficiency of $6.8 \%$. Kang [23] chose the working fluid R245fa with a radial turbine directly connected to a high-speed synchronous generator. In the study a maximum cycle efficiency of $5.22 \%$ was shown, generating an electrical power up to $32.7 \mathrm{~kW}$. The same working fluid and a scroll expander were tested in a small-size ORC prototype by Bracco et al. [24]. The heat source was simulated using an electric boiler, achieving a cycle efficiency between 8 and $9 \%$. More working fluids, expander technologies and cycle performances were reviewed by Bao et al. [25].

Besides technical and thermodynamic issues, the economic viability also plays a key role in a project development. In this way Casci et al. [26] used an ORC, with a rated electrical power of $40 \mathrm{~kW}$, in a ceramic kiln to profit from flue gas waste heat, concluding about a payback period between 2.5 and 4 years. Jung et al. [27] developed a financial model to examine the technical and economic feasibility of a $250 \mathrm{~kW}$ ORC for low-grade waste heat recovery in a petroleum refinery. The authors concluded that, in compliance with a target cost of $\$ 3000 / \mathrm{kW}$ for a feasible system, a reasonable internal rate of return of $21.8 \%$ and a payback period of 6.8 years could be achieved. David et al. [28] presented two cases studied of waste heat recovery: valorization of hot gases from a coking plant in a steel mill and a valorization of exhaust from a biogas engine. The authors pointed that the first one suffered from a low electricity price that did not allow this project, since the payback time of the investment rounded 8 and 9 years. In contrast, the second one resulted economically viable due to a supporting measure that allowed a payback time under 5 years. Forni et al. [29] summarized various analysis of an ORC manufacturer in cement, glass, steel and oil\&gas industries. The net electrical production went from 7.6 to $39.2 \mathrm{GWh} / \mathrm{y}$, allowing payback periods from 7.2 to 9.2 years, internal rate of returns about 9 and $13 \%$ and avoiding up to 24,696 t/y of $\mathrm{CO}_{2}$ gas emissions. 
Regarding to ORC manufacturers, each one is focused on a specific power range, heat source temperatures, working fluid and expansion technology, as it is summarized in Table 2.

Table 2. Main characteristics of commercial ORC systems.

The reviewed information has shown that the ORC is a promising technology for waste heat recovery. However, there are few works in literature that show the actual performance of ORC systems implemented in industrial processes. In this way, this work conducts an experimental characterization of an ORC integrated in an industrial process for low grade waste heat recovery. The ORC module used in this application was optimized during design and construction phases, achieving an efficient power system, as was demonstrated in laboratory tests of a previous work [37]. Thus, the aim of this paper is to validate the actual performance of the system in the industrial application, discussing and comparing the results to laboratory data. Moreover, making use of all these experimental results, a model of the recovery system is developed, allowing predicting the net electrical production in function of heat source and heat sink conditions. The model is used to quantify the electrical generation during a typical year of operation, as well as conducting a close feasibility study.

For this purpose, the rest of the paper is organized as follows. Section 2 presents the application case, describing the main parts of the recovery facility. Section 3 exposes the methodology employed for the system characterization, pointing the measuring devices used, uncertainties, thermodynamic analysis equations, test procedure and model proposed of the system. Section 4 describes the main results of the system characterization, validates the model and simulates the electrical production during a year of operation to quantify the energy, environmental and economic benefits of the project. Finally, section 5 summarizes the main conclusions of the work.

\section{Facility description}

In this section the main parts of the recovery facility are going to be briefly presented.

\subsection{Heat source}

This application consists of profiting waste heat from exhaust gases of a ceramic furnace. Specifically, recovering the waste heat available in the indirect cooling air, that are clean gases with high temperature due to its proximity to the burners of the furnace. The recovery facility is mainly composed by a recuperator heat exchanger, located in the bypass of the cooling air, and a heat transfer loop with thermal oil that transports the thermal energy from the heat source to the ORC module, as Fig. 1 shows.

Fig. 1. Industrial furnace of Keros Ceramica and heat recovery facility: (a) bypass view, (b) heat transfer loop view.

The main features of the recuperator heat exchanger are listed in Table 3. This heat exchanger was designed to recover a thermal power of $177 \mathrm{~kW}$ from the heat source and provide thermal oil at $165^{\circ} \mathrm{C}$ to the ORC module.

Table 3. Recuperator heat exchanger features. 


\subsection{Heat sink}

As usual in the case of ORC modules for power generation, the dissipation system is directly implemented through an air condenser. This system allows reducing exergetic losses compared to a dry cooler with cooling water, besides simplifying the scheme, since there is not required another pump nor its associated safety and control devices.

The main air condenser features are listed in Table 4. This condenser was designed with oversize in order to maximize the final electricity produced, since a high heat exchange surface allows reducing the fans velocity and, consequently, the electrical power consumption.

Table 4. Air condenser features.

\subsection{ORC module}

The ORC used in this application is a commercial module from Rank® [34], shown in Fig. 2, that was optimized during design and construction phases. So, the system has a regenerative configuration that allows not only recovering the thermal energy from the heat source, but also the waste heat from the expander outlet to preheat the liquid, improving the cycle electrical efficiency. The working fluid used is R245fa, commonly used among the reviewed ORC manufacturers, since it is a non flammable fluid with low toxicity (permissible exposure level about $300 \mathrm{ppm}$ ) and moderate environmental properties, which also has been proven as an efficient fluid for low grade waste heat recovery [38]. Moreover, the large built-in volume ratio of the expander allows operating with high efficiencies in power applications, as Clemente et al. [39] demonstrated. These and other features of the ORC module are listed in Table 5.

Fig. 2. ORC module and dissipation system [18].

Table 5. Rank® ORC module features.

\section{Methodology}

In this section the main measuring devices used for the system monitoring, equations for the experimental data analysis, test procedure conducted and modeling methodology proposed are addressed.

\subsection{System monitoring}

Focusing on the ORC monitoring, the main parameters measured are represented in Fig 3. In the first place, the thermal power input is monitored in the hot side through inlet and outlet thermal oil temperatures, using surface thermocouples, and the thermal oil volumetric flow rate, which is measured using a vortex flow meter. From the thermal power input, the working fluid mass flow rate can be obtained through temperature and pressure conditions at the HRVG (heat recovery vapor generator) ports. Thus, two surface thermocouples and a single pressure transmitter are employed, neglecting the HRVG pressure drop. The pressure and temperature devices from the HRVG outlet are placed as near as possible to the expander inlet port, as well as two more transmitters at the expander outlet port for monitoring its performance. The electrical power of the system is measured through wattmeter devices, situated in the electric generator for the gross power measurement, the electric motor of the pump to determine the cycle net power and at the connection of the system to the grid of the factory for the injected 
electricity measurement. On the other hand, the cold side influence is also considered by a temperature device placed near the air suction of the condenser.

Fig.3. Regenerative ORC scheme and main parameters monitored.

The measuring devices uncertainties, extracted from manufacturers' data sheets, and the calculated parameters uncertainties $U_{y}$, obtained as a function of the uncertainty on each measured variable $U_{x_{i}}$ by Eq. (1) [20], are collected in Table 6 distinguishing between uncertainty values from laboratory tests and uncertainty values from the tests conducted in the industrial application.

$U_{y}=\sqrt{\sum_{i=1}^{N}\left(\frac{\partial y}{\partial x_{i}}\right)^{2} \cdot U_{x_{i}}^{2}}$

Table 6. Uncertainties of measured and calculated parameters from laboratory tests and industrial application tests.

\subsection{Thermodynamic analysis equations}

For the analysis of the experimental data obtained during tests various equations have been used. Firstly, the thermal power input is calculated through Eq. (2) and the thermal oil properties at the operating conditions. From this, the working fluid mass flow rate can be obtained by Eq. (3). The working fluid properties have been evaluated using software REFPROP [40].

$$
\begin{aligned}
& Q_{\text {in }}=\rho_{\text {oil }, \text { out }} \cdot \dot{V}_{\text {oil,out }} \cdot c_{\text {poil }} \cdot\left(T_{\text {oil ,in }}-T_{\text {oil }, \text { out }}\right) \\
& \dot{m}_{w f}=\frac{Q_{\text {in }}}{h_{e, \text { in }}-h_{H R V G, \text { in }}}
\end{aligned}
$$

The gross electrical power from the electric generator is directly measured, as well as the electrical pump consumption and, therefore, it can be calculated the net power output generated using Eq. (4). Furthermore, the net power of the ORC considering condenser and other internal electrical consumptions is defined as Eq. (5), which also is directly measured. The cycle efficiency is obtained using the gross electrical efficiency by Eq. (6) and net electrical efficiency by Eq. (7). Moreover, the relationship between the electrical power measured in the electric generator and the maximum that could be ideally obtained in the expander is defined as the electrical isentropic effectiveness, often also named expander overall efficiency, by Eq. (8).

$$
\begin{aligned}
& W_{n}=W_{g}-W_{p} \\
& W_{\text {ORC }}=W_{n}-W_{\text {other }} \\
& \eta_{g}=\frac{W_{g}}{Q_{i n}} \\
& \eta_{n}=\frac{W_{n}}{Q_{i n}}
\end{aligned}
$$


$\varepsilon_{e l, \text { ise }}=\frac{W_{g}}{\dot{m}_{w f} \cdot\left(h_{e, \text { in }}-h_{e, \text { out }, \text { ise }}\right)}$

Other parameters calculated and used for the analysis are the pressure ratio in the expander, defined by Eq. (9), and Carnot efficiency, by Eq. (10) with temperatures in Kelvin units.

$$
\begin{gathered}
r_{p}=\frac{P_{e, \text { in }}}{P_{e, \text { out }}} \\
\eta_{\text {Carnot }}=1-\frac{T_{\text {ambient }}}{T_{\text {oil }, \text { in }}}
\end{gathered}
$$

\subsection{Test procedure}

The ORC module was tested under different performance curves of the furnace, related to different tiles dimensions or materials. For this, the control of the thermal oil volumetric flow rate was imposed with a fixed frequency set point in the pump inverter. On the other hand, the ambient temperature cannot be controlled, however different operating conditions have been achieved during tests.

As a result, 17 steady state points were achieved. The process of selecting steady state points consisted of taking a time period of $15 \mathrm{~min}$, with a sample period of $1 \mathrm{~s}$, in which the measured parameters were within a fluctuation range lower than $1 \%$ on each variable. Once a steady state was achieved (with 900 direct measurements), the data measured were obtained averaging over a time period of $10 \mathrm{~min}$ (600 direct measurements).

The operating range registered for each variable during tests is listed in Table 7.

Table 7. Operating range of each variable during tests.

\subsection{System modeling}

The model is a tool for the system performance simulation within the operating range obtained during tests. Thus, it is developed as a regression equation that provides the net electrical power output of the ORC, only excluding the thermal oil pump consumption, from the input variables. From all the measured variables during tests, conducted in laboratory and the industrial application, an analysis of the significance of each variable on the net electrical power was conducted. As a result, a model is proposed directly using the thermal oil inlet temperature and thermal oil volumetric flow rate, representative of the hot side influence, besides the ambient temperature, representative of the cold side influence. This model is schematized in Fig. 4.

Fig. 4. Recovery system model.

The model is defined as Eq. (11), a regression equation that has a coefficient of determination $\left(R^{2}\right)$ of 0.99 , indicative of a proper prediction. The parameters used in this equation are listed in Table 8.

$$
W_{\text {ORC }}=a_{0}+a_{1} \cdot T_{\text {oil }, \text { in }}+a_{2} \cdot \dot{V}_{\text {oil }, \text { out }}+a_{3} \cdot T_{\text {ambient }}
$$


Table 8. Model parameters.

To assess the predictive method, a statistical analysis is conducted based on the mean percentage error of the predicted value with respect to the experimental value. Moreover, the mean average error and the standard deviation are also considered in the statistical analysis. Each parameter is defined respectively as Eq. (12)-(15).

$$
\begin{aligned}
& \chi_{i}=\left(\frac{x_{\text {model }, i}-x_{\text {experimental }, i}}{x_{\text {experimental }, i}}\right) \\
& \bar{\chi}=\frac{1}{N} \cdot \sum_{i=1}^{N} \chi_{i} \\
& |\bar{\chi}|=\frac{1}{N} \cdot \sum_{i=1}^{N}\left|\chi_{i}\right| \\
& \sigma=\sqrt{\frac{1}{N} \cdot \sum_{i=1}^{N}\left(\chi_{i}-\bar{\chi}\right)^{2}}
\end{aligned}
$$

\section{Results and discussions}

From the experimental data obtained during tests an analysis has been conducted, whose results are exposed and discussed in this section. Moreover, the model is statistically validated according to experimental data and the electrical production is simulated, leading to a feasibility study.

\subsection{Experimental characterization}

In a first step, the thermal power characterization is addressed. Fig. 5.a shows that higher thermal oil temperatures allow higher thermal power captures by the ORC. This is due to the control conducted by ORC. So, when the thermal oil temperature raises, also the working fluid temperature increases, as Fig. 5.b shows. The control of the ORC takes into account this change and maintains a superheating degree within a permissible operating range. Thereby, for higher temperatures in the expander inlet port, the pressure of the cycle increases, as can be seen in Fig. 5.c, which corresponds to a higher working fluid mass flow rate, as Fig. 5.d shows.

Comparing to laboratory data, the operation in the industrial application allows recovering more thermal power input, since higher thermal oil temperatures are achieved. Thus, while in the laboratory the maximum thermal power input was $146.41 \mathrm{~kW}$ with a thermal oil inlet temperature of $155.70{ }^{\circ} \mathrm{C}$, in the industrial application up to $179.87 \mathrm{~kW}$ with a temperature of $167.46^{\circ} \mathrm{C}$ are achieved.

Fig.5. Thermal power characterization: (a) thermal oil inlet temperature, (b) expander inlet temperature, (c) expander inlet pressure, (d) working fluid mass flow rate.

When the system captures more thermal power, in this case mainly due to the rise of the thermal oil temperature, the gross and net electrical production also increases, as Fig. 6.a and Fig. 6.b show. Therefore, since in the industrial application more thermal power is captured, more 
electrical power is obtained. In this way, near $22 \mathrm{~kW}$ of gross electrical power is achieved, compared to the maximum of about $18 \mathrm{~kW}$ obtained in laboratory.

Fig.6. Electrical power characterization: (a) gross electricity with thermal input, (b) net electricity with thermal input.

Regarding to efficiencies, Fig.7.a represents the gross electrical efficiency of the cycle. It can be seen that the efficiency tendency grows with the pressure ratio up to a maximum of $12.47 \%$, slightly higher than the $12.32 \%$ from laboratory results. Similar, the net electrical efficiency, represented in Fig. 7.b, arrives up to a maximum of $10.94 \%$, also slightly higher than the 10.88 $\%$ obtained in laboratory.

If the net electrical efficiency is compared to the ideally Carnot efficiency in Fig. 7.c, it can be observed that the cycle efficiency tendency appears to be attenuated for the highest values. This effect can be justified observing Fig. 7.d referred to the expander. So, the electrical isentropic effectiveness of the expander is maximized about $65 \%$ for a pressure ratio near 8 , imposed by the expander built-in volume ratio, that is a suitable operating range for a power application from low grade heat sources. This figure also shows the energy losses produced when the expander operates in under-expansion and, still more, in over-expansion. Other energy losses that contribute to draw this curve are heat losses during expansion, frictions, supply pressure drop, internal leakages [41], or the alternator electrical efficiency operating at partial loads [42].

Fig.7. Thermodynamic efficiencies characterization: (a) gross electrical efficiency, (b) net electrical efficiency, (c) Carnot efficiency, (d) expander electrical isentropic effectiveness.

\subsection{Electrical production}

As it can be seen in Fig. 8, the model is validated within an error bandwidth of $\pm 5 \%$ including uncertainties, being the model a practical method to predict the system performance. The results of the statistical analysis are listed in Table 9, highlighting the small error and standard deviation values.

Fig. 8. Model validation.

Table 9. Statistical analysis parameters.

Based on the validated model, the electrical production simulation during a typical year of operation can be obtained, as Fig. 9 shows. In order to do this, a test with the experimental data corresponding to a complete week has been obtained, managed as hourly averaged data. Furthermore, the ambient temperature has been obtained of a typical year from a historical register of the location where the industry is situated. Thereby, both hot and cold sides of a typical year are estimated. Regarding to the ORC electrical production, it was considered that the heat recovery system operates while the furnace works (all the year except one month for furnace maintenance tasks, specifically august). Thereby, the net electrical production is quantified about $121 \mathrm{MWh}$, as Table 10 lists. If the thermal oil pump consumption is considered, as a fixed electrical power consumption of $0.7 \mathrm{~kW}$, the final electrical production injected into the grid of the factory is quantified over $115 \mathrm{MWh}$. This generation could save near $237 \mathrm{MWh}$ of primary energy, similarly as occurs in cogeneration power plants [43], and avoid about $31 \mathrm{t} / \mathrm{y}$ of equivalent $\mathrm{CO}_{2}$ emissions, considering the country energy mix [44]. 
Fig. 9. Electrical production simulation.

\subsection{Feasibility study}

As mentioned above, the final electrical production is about $115 \mathrm{MWh}$, taking into consideration the internal electrical consumptions of the whole recovery system and heat source and heat sink fluctuations. Based on this more realistic electrical production, a feasibility study is addressed.

For this, the national electricity price for industrial consumers and its annual percentage growth have been used [45]. It can be noted that the facility expenditure is linked to an experimental project, not disposing of realistic selling costs. Therefore, the following costs exposed are only referred to indications of the ORC manufacturer about the set of ORC module and dissipation system.

Thereby, the results show that the payback is 4.63 years, which is considered as economically viable in the literature [28]. Furthermore, acceptable internal rate of returns and net present values are obtained.

Table 10. Feasibility study.

\section{Conclusions}

This work has characterized the performance of an ORC operating in an industrial application for low grade waste heat recovery. So, 17 steady state points have been achieved, analyzed and compared to laboratory data.

The results show that the thermal power captured by the ORC and the electrical power produced increase for higher thermal oil temperatures. So, since higher thermal oil temperatures have been obtained during tests in the industrial application, higher electrical powers have been generated compared to laboratory tests. However, regarding to efficiency of the cycle and effectiveness of the expander there were no major variations.

Regarding to experimental data summary, the thermal power input ranged from $128.19 \mathrm{~kW}$ to $179.87 \mathrm{~kW}$. The maximum gross and net electrical powers achieved are $21.79 \mathrm{~kW}$ and 18.51 $\mathrm{kW}$, respectively. The maximum cycle efficiencies reached are a gross electrical efficiency of $12.47 \%$ and a net electrical efficiency of $10.94 \%$. Moreover, the expander achieved a maximum electrical isentropic effectiveness of $64.89 \%$ for an optimum pressure ratio near 8 , imposed by the expander built-in volume ratio, which is a suitable value for power applications from low grade heat sources.

From the ORC performance data of laboratory and industrial application tests, a model of the recovery system has been developed. The model allows predicting the net electrical power using thermal oil inlet temperature, thermal oil volumetric flow rate and ambient temperature as input parameters. This model has been validated with an error bandwidth of $\pm 5 \%$.

Using the model, the electrical production of the system during a typical year of operation has been simulated, obtaining a final energy production above $115 \mathrm{MWh}$. This generation could 
save near $237 \mathrm{MWh}$ of primary energy and avoid about $31 \mathrm{t} / \mathrm{y}$ of equivalent $\mathrm{CO}_{2}$ emissions to the atmosphere. Furthermore, the feasibility study reveals that the payback is 4.63 years, with an acceptable internal rate of return and net present value.

\section{Acknowledgments}

The authors are indebted to the Minister of industry of 'Generalitat Valenciana' (Spain) for its financial assistance under project INIDIV2010022 and Rank®, the ORC manufacturer, for its support in this project. Also to thank greatly the Jaume I University for its financial support under the $\mathrm{PhD}$ grant $\mathrm{PREDOC} / 2013 / 28$ of 'Convocatòria d'ajudes predoctorals per a la formació de personal investigador del Pla de promoció de la investigació de la Universitat Jaume I de Castelló (Spain)'.

\section{References}

[1] Yamada N, Tominaga Y, Yoshiba T. Demonstration of $10-\mathrm{W}_{\mathrm{p}}$ micro organic Rankine cycle generator for low-grade heat recovery. Energy 2014; 78: 806-813.

[2] Li J, Pei G, Li Y, Wang D, Ji J. Energetic and exergetic investigation of an organic Rankine cycle at different heat source temperatures. Energy 2012; 38: 85-95.

[3] Bombarda P, Invernizzi CM, Pietra C. Heat recovery from Diesel engines: A thermodynamic comparison between Kalina and ORC cycles. Applied Thermal Engineering 2010; 30: 212-219.

[4] Chen H, Goswami DY, Stefanakos EK. A review of thermodynamic cycles and working fluids for the conversion of low-grade heat. Renewable and Sustainable Energy Reviews 2010; 14: $3059-3067$.

[5] Tchanche BF, Lambrinos Gr, Frangoudakis A, Papadakis G. Low grade heat conversion into power using organic Rankine cycles - A review of various applications. Renewable and Sustainable Energy Reviews 2011; 15: 3963-3979.

[6] Wang M, Wang J, Zhao Y, Zhao P, Dai Y. Thermodynamic analysis and optimization of a solar-driven regenerative organic Rankine cycle (ORC) based on flat-plate solar collectors. Applied Thermal Engineering 2013; 50: 816-825.

[7] Franco A. Power production from a moderate temperature geothermal resource with regenerative Organic Rankine Cycles. Energy for Sustainable Development 2011; 15: 411-419.

[8] Algieri A, Morrone P. Comparative energetic analysis of high-temperature subcritical and transcritical Organic Rankine Cycle (ORC). A biomass application in the Sibari district. Applied Thermal Engineering 2012; 36: 236-244.

[9] Aussant CD, Fung AS, Ugursal VI, Taherian H. Residential application of internal combustion engine based cogeneration in cold climate - Canada. Energy and Buildings 2009; 41: $1288-1298$. 
[10] Dolz V, Novella R, García A, Sánchez J. HD Diesel engine equipped with a bottoming Rankine cycle as a waste heat recovery system. Part 1: Study and analysis of the waste heat energy. Applied Thermal Engineering 2012; 36: 269-278.

[11] Wang D, Ling X, Peng H. Performance analysis of double organic Rankine cycle for discontinuous low temperature waste heat recovery. Applied Thermal Engineering 2012; 48 : 63-71.

[12] Wang H, Peterson R, Herron T. Design study of configurations on system COP for a combined ORC (organic Rankine cycle) and VCC (vapor compression cycle). Energy 2011; 36: 4809-4820.

[13] Campana F, Bianchi M, Branchini L, Pascale AD, Peretto A, Baresi M, Fermi A, Rossetti N, Vescovo R. ORC waste heat recovery in European energy intensive industries: Energy and GHG savings. Energy Conversion and Management 2013; 76: 244-252.

[14] Wang HT, Wang H, Zhang ZM. Optimization of Low-Temperature Exhaust Gas Waste Heat Fueled Organic Rankine Cycle. Journal of Iron and Steel Research, International 2012; 19: 30-36.

[15] Ammar Y, Joyce S, Norman R, Wang Y, Roskilly AP. Low grade thermal energy sources and uses from the process industry in the UK. Applied Energy 2012; 89: 3-20.

[16] Zhou N, Wang X, Chen Z, Wang Z. Experimental study on Organic Rankine Cycle for waste heat recovery from low-temperature flue gas. Energy 2013; 55: 216-225.

[17] Aneke M, Agnew B, Underwood C, Wu H, Masheiti S. Power generation from waste heat in a food processing application. Applied Thermal Engineering 2012; 36: 171-180.

[18] Navarro-Esbrí J, Peris B, Collado R, Molés F. Micro-generation and micro combined heat and power generation using "free" low temperature heat sources through Organic Rankine Cycles. Paper 390. International Conference on Renewable Energies and Power Quality. Bilbao (Spain); 2013.

[19] Wang T, Zhang Y, Peng Z, Shu G. A review of researches on thermal exhaust heat recovery with Rankine cycle. Renewable and Sustainable Energy Reviews 2011; 15: 28622871.

[20] Lemort V, Quoilin S, Cuevas C, Lebrun J. Testing and modeling a scroll expander integrated into an Organic Rankine Cycle. Applied Thermal Engineering 2009; 29: 3094-3102.

[21] Quoilin S, Lemort V, Lebrun J. Experimental study and modeling of an Organic Rankine Cycle using scroll expander. Applied Energy 2010; 87: 1260-1268.

[22] Pei G, Li J, Li Y, Wang D, Ji J. Construction and dynamic test of a small-scale organic rankine cycle. Energy 2011; 36: 3215-3223.

[23] Kang SH. Design and experimental study of ORC (organic Rankine cycle) and radial turbine using R245fa working fluid. Energy 2012; 41: 514-524. 
[24] Bracco R, Clemente S, Micheli D, Reini M. Experimental tests and modelization of a domestic-scale ORC (Organic Rankine Cycle). Energy 2013; 58: 107-116.

[25] Bao J, Zhao Li. A review of working fluid and expander selections for organic Rankine cycle. Renewable and Sustainable Energy Reviews 2013; 24: 325-342.

[26] Casci C, Angelino G, Ferrari P, Gaia M, Giglioli G, Macchi E. Heat recovery in a ceramic kiln with an organic Rankine cycle engine. Journal of Heat Recovery Systems 1981; 1: 125131.

[27] Jung HC, Krumdieck S, Vranjes T. Feasibility assessment of refinery waste heat-to-power conversion using an organic Rankine cycle. Energy Conversion and Management 2014; 77: 396-407.

[28] David G, Michel F, Sanchez L. Waste heat recovery projects using Organic Rankine Cycle technology - Examples of biogas engines and steel mills applications. World engineers' convention. Geneva (Switzerland); 2011.

[29] Forni D, Rossetti N, Vaccari V, Baresi M, Santo DD. Heat recovery for electricity generation in industry. ECEEE, Summer Study on Energy Efficiency in Industry. Arnhem (The Netherlands); 2012.

[30] Vélez F, Segovia JJ, Martín MC, Antolín G, Chejne F, Quijano A. A technical, economical and market review of organic Rankine cycles for the conversion of low-grade heat for power generation. Renewable and Sustainable Energy Reviews 2012; 16: 4175- 4189.

[31] Bianchi M, Pascale AD. Bottoming cycles for electric energy generation: Parametric investigation of available and innovative solutions for the exploitation of low and medium temperature heat sources. Applied Energy 2011; 88: 1500-1509.

[32] Enertime. Paris, France. Available from: <www.enertime.com> [accessed 25.03.15].

[33] Phoenix. Port Melbourne, Australia. Available from: <www.phoenixorc.com.au> [accessed 25.03.15].

[34] Rank®. Castellon, Spain. Available from: <www.rankweb.es> [accessed 25.03.15].

[35] Zuccato Energia. Verona, Italy. Available from: <www.zuccatoenergia.it> [accessed 25.03.15].

[36] Quoilin S, Broek MVD, Declaye S, Dewallef P, Lemort V. Techno-economic survey of Organic Rankine Cycle (ORC) systems. Renewable and Sustainable Energy Reviews 2013; 22: 168-186.

[37] Peris B, Navarro-Esbrí J, Molés F, Collado R, Mota-Babiloni A. Performance evaluation of an Organic Rankine Cycle (ORC) for power applications from low grade heat sources. Applied Thermal Engineering 2015; 75: 763-769.

[38] Peris B, Navarro-Esbrí J, Molés F. Bottoming organic Rankine cycle configurations to increase Internal Combustion Engines power output from cooling water waste heat recovery. Applied Thermal Engineering 2013; 61: 364-371. 
[39] Clemente S, Micheli D, Reini M, Taccani R. Energy efficiency analysis of Organic Rankine Cycles with scroll expanders for cogenerative applications. Applied Energy 2012; 97: 792-801.

[40] Lemmon E, Huber M, McLinden M. NIST REFPROP standard reference database 23. Version 8.0. User's guide. NIST; 2007.

[41] Ibarra M, Rovira A, Alarcón-Padilla DC, Blanco J. Performance of a 5 kWe Organic Rankine Cycle at part-load operation. Applied Energy 2014; 120: 147-158.

[42] Erhart T, Eicker U, Infield D. Part-load characteristics of Organic-Rankine-Cycles. 2nd European Conference on Polygeneration. Tarragona, Spain; 2011.

[43] Directive 2012/27/UE of the European Parliament of the Council of 25 October 2012 relative to energy efficiency. Official Journal of the European Union; 2012.

[44] A practical guide for calculating emissions of greenhouse gases. Guia pràctica per al càlcul d'emissions de gasos amb efecte d'hivernacle (GEH). Oficina Catalana del Canvi Climàtic (OCCC); Cataluña (Spain) 2014. < canviclimatic.gencat.cat> [accessed 25.03.15].

[45] Commission of the European Communities; European Commission. EUROSTATstatistical book: Electricity prices for industrial consumers, from 2007 onwards bi-annual data. <ec.europa.eu/eurostat/web/energy/data/database> [accessed 25.03.15]. 


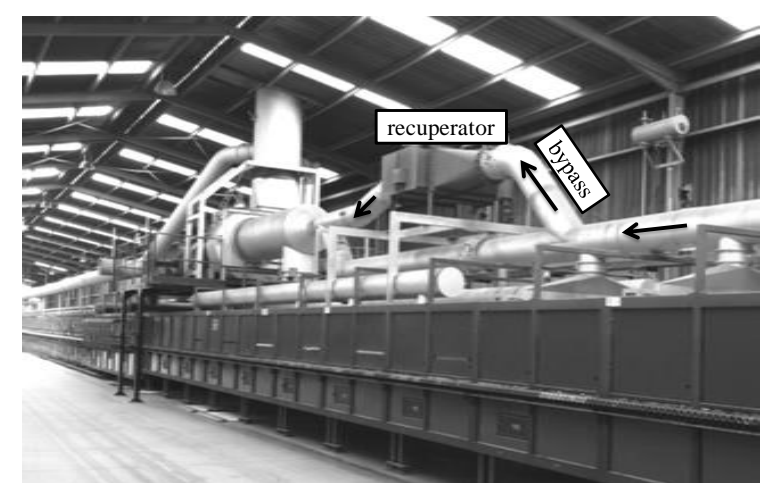

(a)

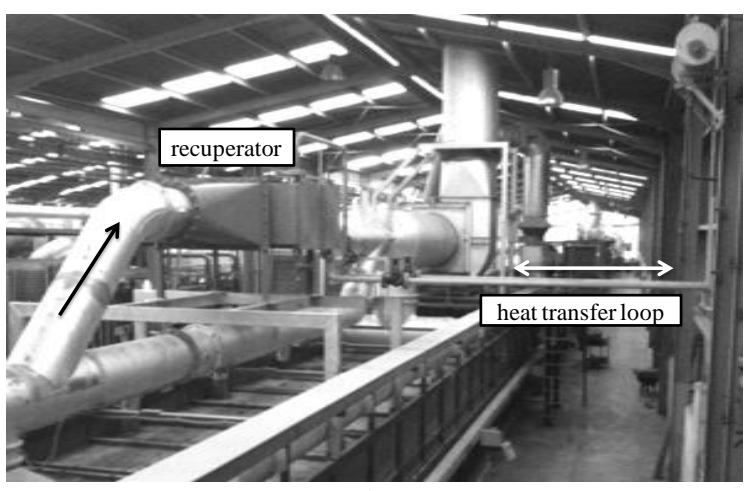

(b)

Fig. 1. Industrial furnace of Keros Ceramica and heat recovery facility: (a) bypass view, (b) heat transfer loop view. 


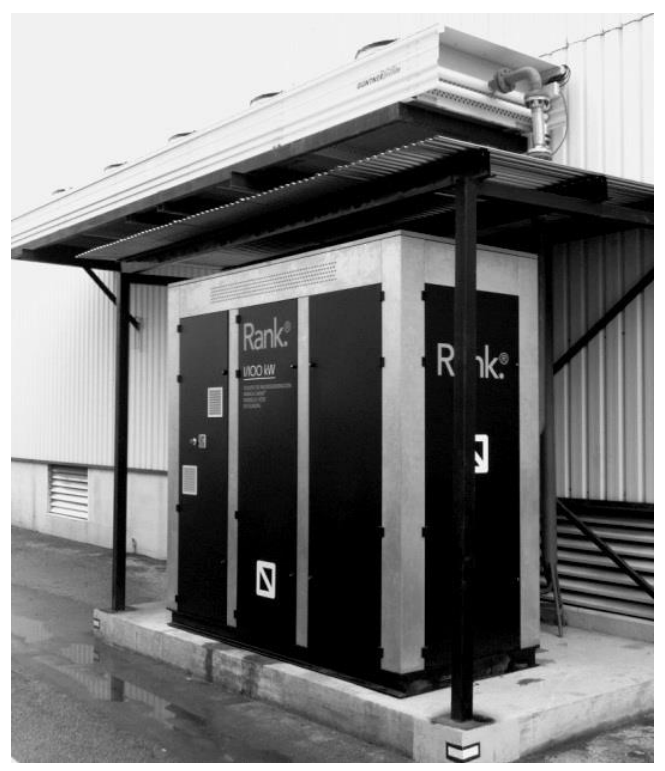

Fig. 2. ORC module and dissipation system [18]. 


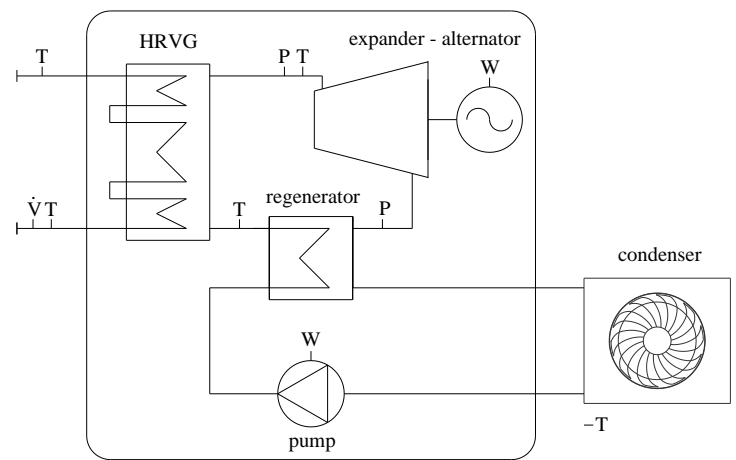

Fig.3. Regenerative ORC scheme and main parameters monitored. 


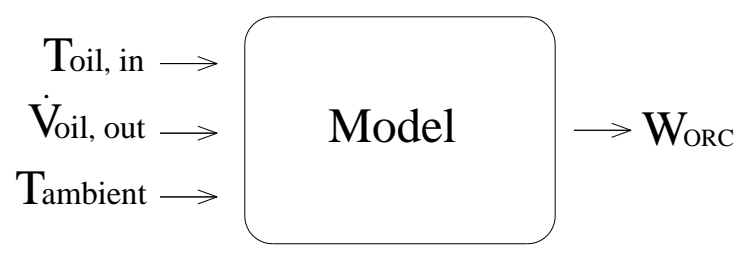

Fig. 4. Recovery system model. 


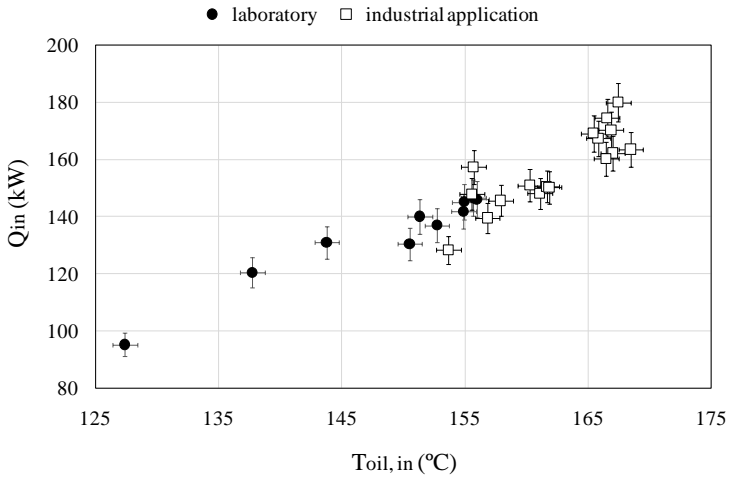

(a)

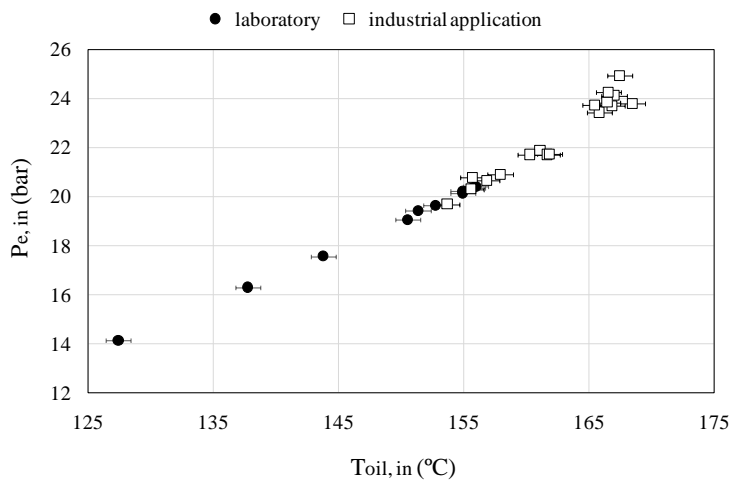

(c)

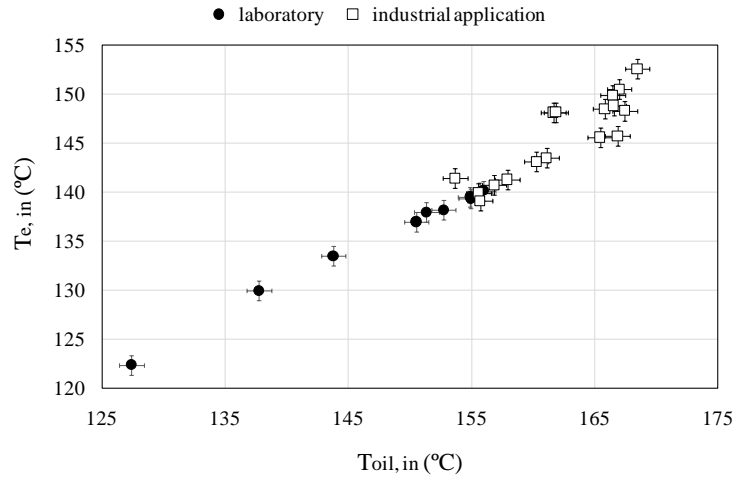

(b)

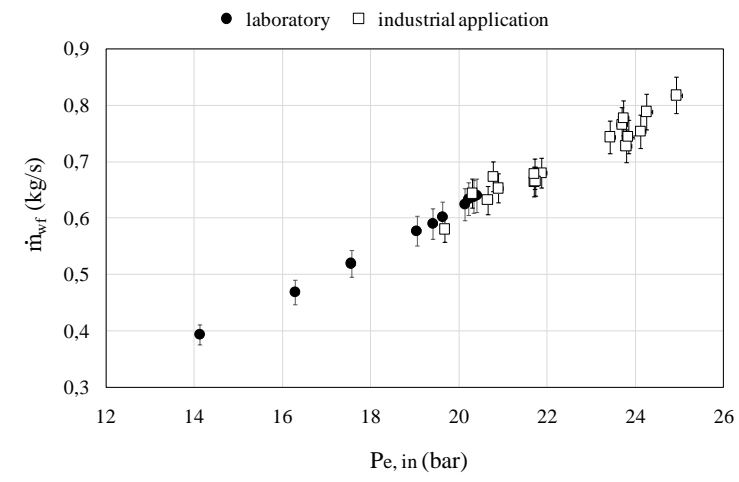

(d)

Fig.5. Thermal power characterization: (a) thermal oil inlet temperature, (b) expander inlet temperature, (c) expander inlet pressure, (d) working fluid mass flow rate. 


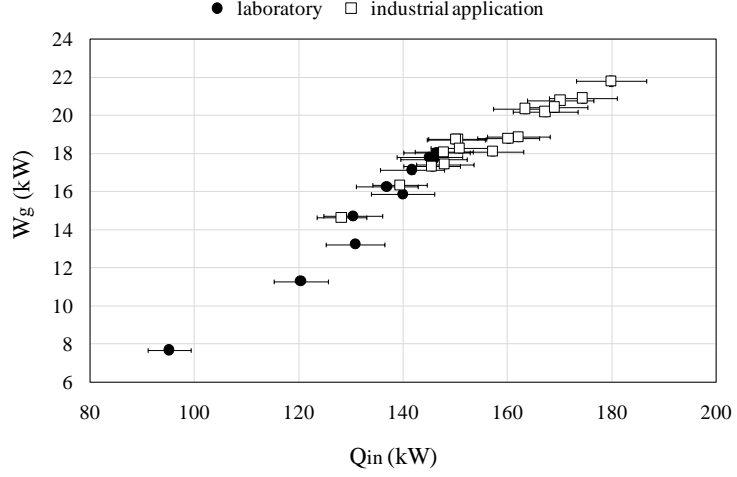

(a)

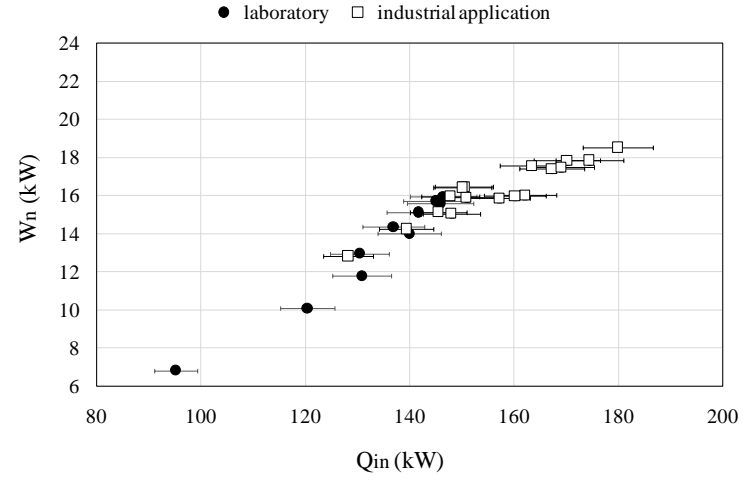

(b)

Fig.6. Electrical power characterization: (a) gross electricity with thermal input, (b) net electricity with thermal input. 


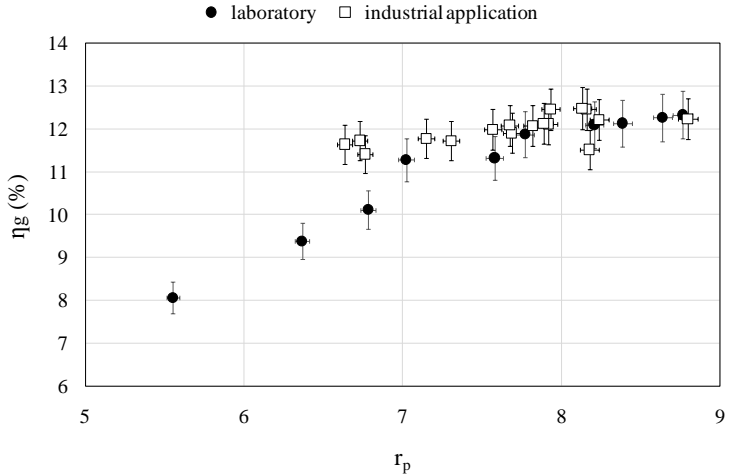

(a)

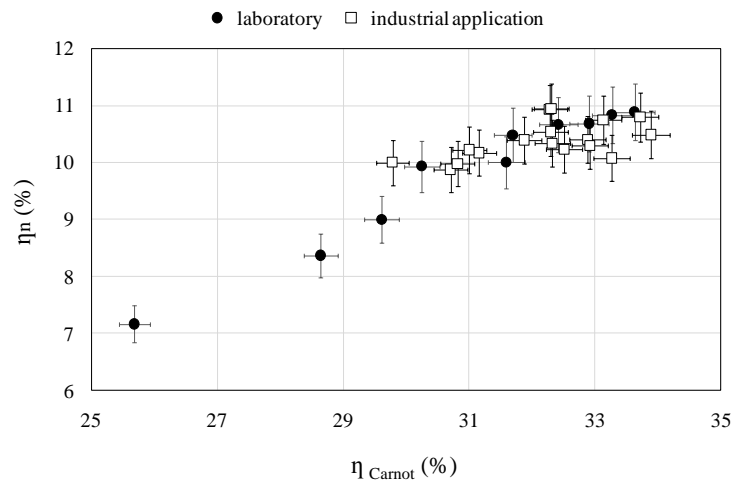

(c)

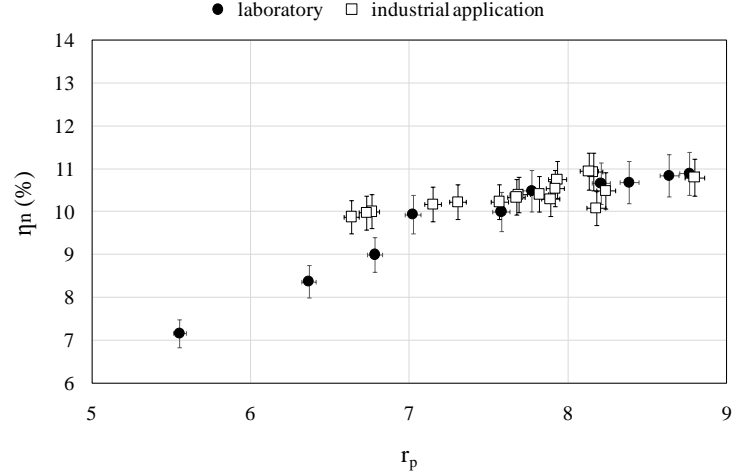

(b)

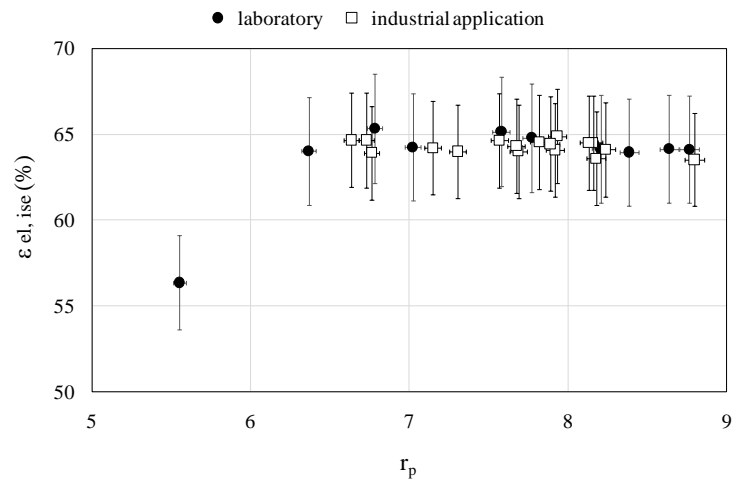

(d)

Fig.7. Thermodynamic efficiencies characterization: (a) gross electrical efficiency, (b) net electrical efficiency, (c) Carnot efficiency, (d) expander electrical isentropic effectiveness. 


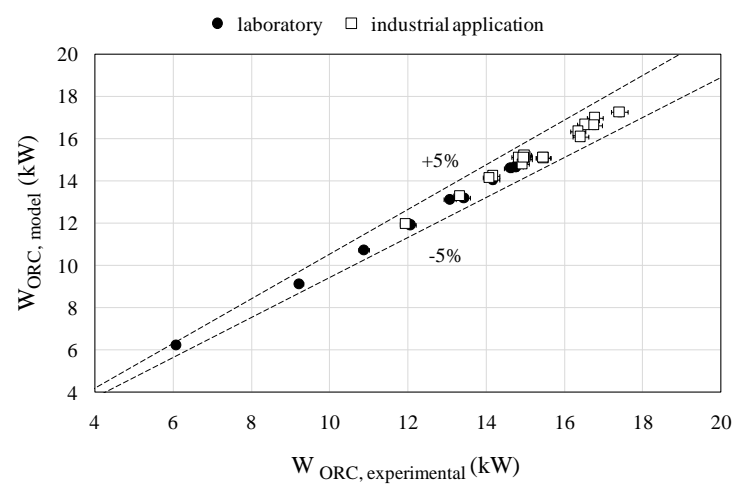

Fig. 8. Model validation. 


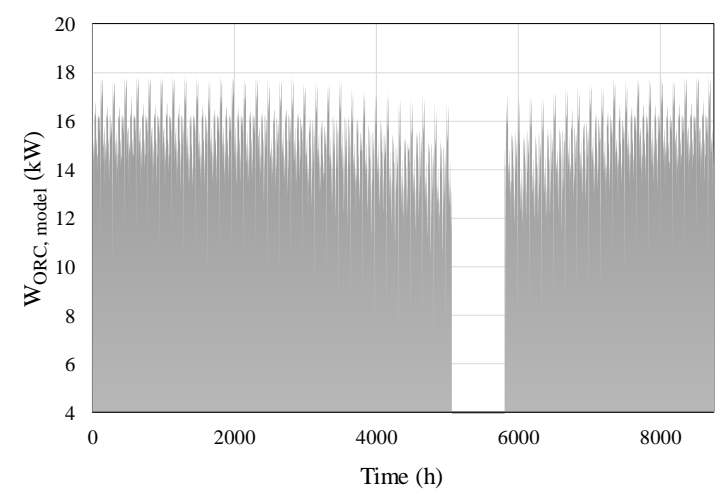

Fig. 9. Electrical production simulation. 


\section{Figure captions}

Fig. 1. Industrial furnace of Keros Ceramica and heat recovery facility: (a) bypass view, (b) heat transfer loop view.

Fig. 2. ORC module and dissipation system [18].

Fig.3. Regenerative ORC scheme and main parameters monitored.

Fig. 4. Recovery system model.

Fig.5. Thermal power characterization: (a) thermal oil inlet temperature, (b) expander inlet temperature, (c) expander inlet pressure, (d) working fluid mass flow rate.

Fig.6. Electrical power characterization: (a) gross electricity with thermal input, (b) net electricity with thermal input.

Fig.7. Thermodynamic efficiencies characterization: (a) gross electrical efficiency, (b) net electrical efficiency, (c) Carnot efficiency, (d) expander electrical isentropic effectiveness

Fig. 8. Model validation.

Fig. 9. Electrical production simulation. 
Table 1. Temperatures of industrial gases.

\begin{tabular}{|c|c|c|c|}
\hline Industry & Process & $\mathrm{T}\left({ }^{\circ} \mathrm{C}\right)$ & Ref. \\
\hline \multirow{2}{*}{ Cement } & Kiln exhaust gases & $200-350 / 300-450$ & \multirow{2}{*}{ [5] } \\
\hline & Kiln cooling gas & $200-300$ & \\
\hline \multirow{5}{*}{ Steel } & Electric arc furnaces & 250 & \multirow{2}{*}[13]{} \\
\hline & Rolling mills & $300-450$ & \\
\hline & Coke oven stack gas & 190 & \multirow{6}{*}[15]{} \\
\hline & Blast furnace stoves & $250-300$ & \\
\hline & Finishing soaking pit & $200-600 / 300-400$ & \\
\hline \multirow{3}{*}{ Glass } & Container glass melting & $160-200 / 140-160$ & \\
\hline & Flat glass & $160-200 / 300-500$ & \\
\hline & Fiberglass melting & $140-160$ & \\
\hline \multirow{4}{*}{ Chemical } & Processing furnaces exhaust & 340 & \multirow{2}{*}[15]{} \\
\hline & Boiler exhaust & 230 & \\
\hline & Refinery gases & $150-300$ & {$[16]$} \\
\hline & Gas turbines & $370-540$ & [5] \\
\hline \multirow[t]{2}{*}{ Food } & Fryers & $120-212$ & \multirow{2}{*}[17]{} \\
\hline & Exhaust gases & 164 & \\
\hline Ceramic & Kiln gases & $200-300$ & {$[18]$} \\
\hline Other & Internal combustion engines & $400-550$ & [19] \\
\hline
\end{tabular}


Table 2. Main characteristics of commercial ORC system.

\begin{tabular}{|c|c|c|c|c|c|}
\hline Manufacturers & $\mathrm{W}(\mathrm{kW})$ & $\mathrm{T}\left({ }^{\circ} \mathrm{C}\right)$ & Working Fluid & Expander type & Ref. \\
\hline $\begin{array}{l}\text { Adoratec/Maxxtec } \\
\text { (Germany) }\end{array}$ & $315-1,600$ & 300 & OMTS & Turbine & \multirow{13}{*}{30} \\
\hline Barber Nichols (USA) & $700-2,700$ & $>115$ & - & Turbine & \\
\hline Electratherm, (USA) & $30-50$ & $>88$ & R245fa & Volumetric (Screw) & \\
\hline Eneftech (Switzerland) & may-30 & $120-200$ & R245fa & Volumetric (Scroll) & \\
\hline Freepower (England) & 120 & $>110$ & Hexane & Turbine & \\
\hline $\begin{array}{l}\text { GE Clean Cycle/ Calnetix } \\
\text { (USA) }\end{array}$ & 125 & $>120$ & $\mathrm{R} 245 \mathrm{fa}$ & Turbine (radial) & \\
\hline GMK (Germany) & $50-5,000$ & $120-350$ & GL-160, WL-220 & Turbine (multistage, axial ) & \\
\hline $\begin{array}{l}\text { Infinity turbine (USA) } \\
\text { (USA }\end{array}$ & $10-250$ & $90-120$ & R134a,R245fa & Turbine & \\
\hline Lti REEnergy (Germany) & 30 & $>160$ & - & - & \\
\hline TransPacific (USA) & $100-5,000$ & $<480$ & - & Turbine & \\
\hline Tri-o-gen (Netherlands) & $60-160$ & $>350$ & Toluene & Turbine & \\
\hline Turboden (Italy) & $200-2,000$ & $100-300$ & OMTS, Solkatherm & Turbine (two-stage axial) & \\
\hline $\begin{array}{l}\text { Pratt \& Whitney Systems } \\
\text { (USA) }\end{array}$ & 280 & $90-150$ & $\mathrm{R} 245 \mathrm{fa}$ & Turbine (radial) & \\
\hline Ormat (USA) & $200-70,000$ & $150-300$ & n-pentano, other & Turbine (two-stage axial) & {$[31]$} \\
\hline Enertime (France) & $300-5,000$ & 200 & HFC & Turbine & [32] \\
\hline Phoenix (Australia) & $10-5,000$ & $80-900$ & $\begin{array}{l}\text { R245fa, Novec649, } \\
\text { Cyclohexano }\end{array}$ & $\begin{array}{l}\text { Not specified } \\
\text { (Scroll expander, turbine) }\end{array}$ & [33] \\
\hline Rank (Spain) & $2-100$ & $80,>140$ & R245fa, other & Volumetric & [34] \\
\hline Zuccato Energy (Italy) & 50,150 & $94,>160$ & - & Turbine (radial) & [35] \\
\hline Bosch KWK (Germany) & $65-325$ & $120-150$ & R245fa & Turbine & \multirow{3}{*}{ [36] } \\
\hline Cryostar (France) & $500-15,000$ & $100-400$ & R245fa, R134a & Turbine (radial) & \\
\hline Opcon (Sweden) & $350-800$ & $<120$ & Amomonia & Volumetric (Lysholm) & \\
\hline
\end{tabular}


Table 3. Recuperator heat exchanger features.

Thermal capacity (kW)

Air volumetric flow rate $\left(\mathrm{Nm}^{3} \cdot \mathrm{s}^{-1}\right)$

Air temperatures $\left({ }^{\circ} \mathrm{C}\right)$

Oil temperatures $\left({ }^{\circ} \mathrm{C}\right)$

Air pressure drop (bar)

Thermal oil pressure drop (bar)

Surface $\left(\mathrm{m}^{2}\right)$
$287 / 170$

$165 / 135$

$1.90 \mathrm{E}-03$

0.8

65.6 
Table 4. Air condenser features.

Dissipation capacity $(\mathrm{kW})$

157.90

Air volumetric flow rate $\left(\mathrm{m}^{3} \cdot \mathrm{s}^{-1}\right)$

18.19

Number of fan units

Energy efficiency class

A

Maximum power consumption at full load (kW)

2.19

Surface $\left(\mathrm{m}^{2}\right)$

$1,112.9$ 
Table 5. Rank® ORC module features.

\begin{tabular}{lr}
\hline Alternator rated power $(\mathrm{kW})$ & 20 \\
Rated thermal power input $(\mathrm{kW})$ & 160 \\
ORC configuration & regenerative \\
Working fluid & R245fa \\
Expander technology & volumetric \\
Built-in volume ratio & 8.0 \\
Heat exchangers type & brazed plate \\
Maximum inlet temperature $\left({ }^{\circ} \mathrm{C}\right)$ & 170 \\
Minimum inlet temperature $\left({ }^{\circ} \mathrm{C}\right)$ & 120 \\
\hline
\end{tabular}


Table 6. Uncertainties of measured and calculated parameters from laboratory tests and industrial application tests.

\begin{tabular}{|c|c|c|}
\hline Parameter & $\begin{array}{c}\mathrm{U} \\
\text { laboratory [37] }\end{array}$ & $\begin{array}{c}\mathrm{U} \\
\text { application }\end{array}$ \\
\hline Temperature $\left({ }^{\circ} \mathrm{C}\right)$ & \multicolumn{2}{|c|}{ \pm 1} \\
\hline Pressure (\%) & \multicolumn{2}{|c|}{0.5} \\
\hline Thermal oil volumetric flow rate $(\%)$ & \multicolumn{2}{|c|}{0.75} \\
\hline Electrical power $(\%)$ & \multicolumn{2}{|c|}{1.20} \\
\hline Thermal power input (\%) & 4.33 & 3.73 \\
\hline Working fluid mass flow rate $(\%)$ & 4.54 & 3.95 \\
\hline Net electrical power $(\%)$ & 1.37 & 1.39 \\
\hline Gross cycle electrical efficiency $(\%)$ & 4.50 & 3.92 \\
\hline Net cycle electrical efficiency $(\%)$ & 4.55 & 3.98 \\
\hline Electrical isentropic effectiveness (\%) & 4.89 & 4.26 \\
\hline Pressure ratio $(\%)$ & 0.71 & 0.71 \\
\hline Carnot efficiency (\%) & 0.94 & 0.87 \\
\hline
\end{tabular}


Table 7. Operating range of each variable during tests.

\begin{tabular}{lc}
\hline \multicolumn{1}{c}{ Parameter } & Operating range \\
\hline $\mathrm{T}_{\text {oil in }}\left({ }^{\circ} \mathrm{C}\right)$ & $153.69-168.48$ \\
$\mathrm{~T}_{\text {oil, out }}\left({ }^{\circ} \mathrm{C}\right)$ & $116.43-126.14$ \\
$\dot{\mathrm{V}}_{\text {oil }}\left(\mathrm{m}^{3} \cdot \mathrm{s}^{-1}\right)$ & $1.96 \mathrm{E}-3-2.19 \mathrm{E}-3$ \\
$\mathrm{~T}_{\text {ambient }}\left({ }^{\circ} \mathrm{C}\right)$ & $11.04-31.86$ \\
$\mathrm{P}_{\mathrm{e}, \text { in }}(\mathrm{bar})$ & $19.68-24.92$ \\
$\mathrm{P}_{\mathrm{e} \text { out }}(\mathrm{bar})$ & $2.31-3.63$ \\
$\mathrm{~T}_{\mathrm{e}, \text { in }}\left({ }^{\circ} \mathrm{C}\right)$ & $139.07-152.52$ \\
$\mathrm{~T}_{\mathrm{HRVG}, \text { in }}\left({ }^{\circ} \mathrm{C}\right)$ & $60.91-80.38$ \\
$\mathrm{~W}_{\mathrm{g}}(\mathrm{kW})$ & $14.62-21.79$ \\
$\mathrm{~W}_{\mathrm{p}}(\mathrm{kW})$ & $1.80-3.28$ \\
$\mathrm{~W}_{\text {ORC }}(\mathrm{kW})$ & $11.93-17.40$ \\
\hline
\end{tabular}


Table 8. Model parameters.

\begin{tabular}{lr}
$a_{0}$ & $-3.394125 \mathrm{E}+01$ \\
$a_{1}$ & $2.7387 \mathrm{E}-01$ \\
$a_{2}$ & $1.10689 \mathrm{E}+00$ \\
$a_{3}$ & $-1.511 \mathrm{E}-01$ \\
\hline
\end{tabular}


Table 9. Statistical analysis parameters.

\begin{tabular}{ll}
\hline $\bar{\chi}$ & $-1.05 \mathrm{E}-03$ \\
$|\bar{\chi}|$ & $1.08 \mathrm{E}-02$ \\
$\lambda_{5 \%}$ & $100 \%$ \\
$\sigma$ & $1.28 \mathrm{E}-02$ \\
\hline
\end{tabular}


Table 10 . Feasibility study.

\begin{tabular}{lr}
\hline \multicolumn{2}{c}{ Simulation results } \\
\hline Electrical production $(\mathrm{kWh})$ & 120,886 \\
Thermal oil pump consumption $(\mathrm{kWh})$ & 5,611 \\
Final energy $(\mathrm{kWh})$ & 115,274 \\
Operating time $(\mathrm{h})$ & 8,016 \\
\hline \multicolumn{2}{c}{ Annual cash flow } \\
\hline Electricity cost $(€)$ & 0.1246 \\
Electricity saving $(€)$ & 14,363 \\
Annual maintenance $(€)$ & 1,200 \\
First year cash flow $(€)$ & 13,163 \\
\hline \multicolumn{2}{c}{ Capital expenditure indications } \\
\hline ORC and dissipation system $(€)$ & 60,000 \\
\hline \multicolumn{2}{c}{ Economic results } \\
\hline Net present value, 15 years, $2 \%(€)$ & 138,286 \\
Internal rate of return $(\%)$ & 22.88 \\
Payback time (y) & 4.63 \\
\hline
\end{tabular}

